July - 2005

\title{
Book Review - Reflections on Research, Faculty and Leadership in Distance Education
}

Editor: Michael F. Beaudoin, Oldenburg: Bibliotheks- und Informationssystem der Carl von Ossietzky University, Oldenburg, Germany. Softcover. 141 pages. ISBN: 3814209052

Reviewed by: Don Olcott, Jr. Executive Director, Division of Extended Programs and Summer Session, Western Oregon University

Reflections on Research, Faculty and Leadership in Distance Education by Michael Beaudoin is a mandatory, prerequisite resource for any practitioner, researcher, faculty member, and technology manager who are reflecting upon their role in distance education theory and practice. Whether you are new to the field or are an experienced distance education practitioner, this book is a five star read that will provide you with the philosophical and practical base to reflect upon your own view of the field, your work, and the future of distance education in higher education.

Professor Beaudoin draws upon his distinguished career over two decades of serving as a distance education leader, program manager, writer, presenter, faculty member, researcher, and theorist in the field. Moreover, he has adapted a unique and innovative approach to examining a range of critical issues facing the field by reviewing various articles on distance education practice, theory and research that were published between 1991- present to determine if this literature was still relevant today and how (or if) it provides direction and vision to the next evolution of the field. Professor Beaudoin draws upon literature that focused on the state of research practice, the changing roles of faculty, and the status of leadership in the field.

At a time when the "mainstreaming" of distance education with campus instruction is pervasive across higher education, Beaudoin takes a calculated risk in today's ubiquitous information and technology age to suggest that distance education researchers, practitioners, and leaders must pause and reflect on the field, where it's been, where it's going and how we are going to get there. He asks some very candid questions:

- Where is the literature on "leadership" in distance education? Do we, in fact, know very much about effective leadership in distance education and the skills and attributes that the next generation of leaders will need to move the field forward?

- In an era of unprecedented information and research via the Web, is research that was conducted five years obsolete and irrelevant to today's distance education environment?

- Have faculty roles changed due to technology adoption and/or have faculty roles changed because our views and philosophical basis for what constitutes effective teaching and learning changed? Or both? 
Book Review - Reflections on Research, Faculty and Leadership in Distance Education

- Given the accelerated access to information, research, and other resources, is the quality and precision of today's distance education research lacking in terms of methodological and assessment approaches?

- Has the distance education field made a critical error in viewing distance learning as synonymous with "online teaching and learning” only? We have been combining technologies in course delivery for decades, yet today we throw around words like "blended learning" as if we have created this in the past five years.

Distance education is at a crossroads. Professor Beaudoin has insightfully accentuated this point in his book. In many ways he points out what Yogi Berra told us about leadership and change ... if you don't know where you're going, you're going to end up somewhere else. As the reviewer of this book, I can dispense with "politically correct” jargon and summarize Professor Beaudoin's major points below.

First, the field of distance education does not know where it's going. Perhaps more disconcerting, is that the current generation of practitioners and researchers have a simplistic and irreverent view of previous work and research conducted in the field.

Second, visionary leadership is absent from the field. There's not just a void in the leadership continuum, but the field has failed to draw upon the exponential research and practice on leadership in general to formulate guiding assumptions for leadership in distance education. Today, everyone and no-one is a leader in distance education. In the absence of genuine leadership, people will listen to whomever will step up to the microphone, or in our case, the research journal, the next keynoter, or the next wordsmith who has a new version of an old concept such as "blended learning." Distance learning, distance education, distributed learning, online learning, and the hits just keep on coming. We can't even make up our minds of what to call our field.

Third, today's researchers in the field need to seriously get back to basics. Perhaps most fundamentally, they need to review their literature. I serve on a number of prestigious editorial boards and am mystified to read manuscripts that do not even mention critical research on their particular topic that was done in the past decade by prominent researchers across the globe. This predisposition with "we get to redefine and start all over" because we are the Web generation is doing a disservice to the field and to our colleagues who have contributed to the theory, practice, research, and assessment of distance education.

At a recent conference, a very distinguished faculty member told me that the roles of our best teachers are constantly changing and this was true long before the advent of technology. The best teachers, by nature, are innovative and creative and always searching for better ways to teach, better ways for students to learn, and better ways to measure and assess that the teaching has produced the learning. Perhaps viewed from another perspective, technology does not make average teachers good teachers ... it makes good teachers great teachers and facilitators.

In summary, I applaud Professor Beaudoin for this exemplary piece of work that should be read by every professional in the field. And, this is not because he has all the answers or solutions nor despite that the book is receiving numerous awards for scholarship. In fact, this book's very admission that the field is not addressing these critical issues and is not formulating new leaders and visions, is not creating new transition models for faculty roles, and has not established new standards for research is the book's inherent value. More importantly, this book does not underscore the important contributions and successes of the field. Professor Beaudoin has provided a thoughtful and illuminating expose of the field in 2004. He, like most us, would like to 
ensure that the future leaders of distance education are still writing about the contributions of distance education to higher education in 2024. The choice is ours.

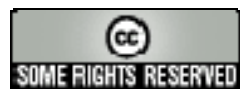

